\title{
ENHANCING LISTENING COMPREHENSION THROUGH FROZEN 2 MOVIE
}

\author{
${ }^{1}$ Ginarti Eka Hamidah \& ${ }^{2}$ Muhamad Sofian Hadi \\ ${ }^{1}$ English Student, FIP, University of Muhammadiyah Jakarta, Indonesia \\ ${ }^{2}$ English Lecturer, FIP, University of Muhammadiyah Jakarta, Indonesia \\ Corresponding Author Email: ginartihamidah112@gmail
}

\begin{tabular}{|c|c|}
\hline Article Info & Abstract \\
\hline $\begin{array}{l}\text { Article History } \\
\text { Received: February } 2021 \\
\text { Revised: April 2021 } \\
\text { Published: April 2021 }\end{array}$ & \multirow{2}{*}{$\begin{array}{l}\text { As an international language, English has become one of the most commonly } \\
\text { spoken languages globally, and mastering the English language is necessary for } \\
\text { us. This research aimed to answer the research question, namely Enhancing } \\
\text { Listening Comprehension Through Frozen } 2 \text { Movie. The researcher wants to } \\
\text { know whether using the Frozen } 2 \text { movie will help students in increasing their } \\
\text { listening comprehension or not. This research using a case study of pre- } \\
\text { experimental as the research design. The study involved } 16 \text { participants of Senior } \\
\text { High School around Griya Serpong Asri, Tangerang. The data was derived from } \\
\text { pre-test and post-test. The researcher collected it during the research time. The } \\
\text { outcome appeared that there is a massive impact on establishing listening } \\
\text { comprehension by watching frozen } 2 \text { movies as media in the learning process. } \\
\text { With the result } 0.003<\alpha(0.05) \text {, which means } H_{1} \text { was accepted and Ho was } \\
\text { rejected. This research shows several advantages of using Frozen } 2 \text { movies as } \\
\text { media in the learning process, such as frozen } 2 \text { movies as interesting media. } \\
\text { Students don't get bored easily by watching the movie. Also, students can learn } \\
\text { body language, facial expressions while listening to the native speaker in the } \\
\text { movie. }\end{array}$} \\
\hline $\begin{array}{l}\text { Keywords } \\
\text { Interesting } \\
\text { Listening; } \\
\text { Listening c }\end{array}$ & \\
\hline
\end{tabular}

How to cite: Hamidah, G. E., \& Hadi, M. S. (2021). Enhancing listening comprehension through Frozen 2 movie, JOLLT Journal of Languages and Language Teaching, 9(2), 139-149, DOI: https://doi.org/10.33394/jollt.v\%vi\%i.3530

\section{INTRODUCTION}

Given the use of the internet and other learning media, exposure to native English speakers nowadays is not tied to students' geographical area. The ability to comprehend English native is essential in non-English dominant countries (Wang, 2016; Wong et al., 2017; Tragant \& Vallbona, 2018). The problem faced by students to comprehend English native is about listening skills. Previous studies on listening difficulties have been paying attention to the perception of reduced forms and long sentences (Makiabadi \& Square, 2019). Therefore, knowing a language is crucial. Roberts et al. (2020) inform students must be used to listen to the language to convey information and complex concept. In listening contexts, language can be a human system to communicate with other creatures, either verbal or nonverbal. Language is a tool to make a relationship with other creatures. Without a language, humans cannot interact or even build good relationships with others. Humans cannot express their feelings, emotions, opinions, ideas, or even ask for help when they need it. Without language, there would be no culture or country.

As stated by Eberhard et al. (2019), that 7.117 languages are spoken today. Languages are distributed unevenly across the world. The countries with the most languages in 2019 were Papua New Guinea with 840 languages, followed by Indonesia with 710 languages, Nigeria with 542 languages, and so on. Based on the obtained finding, there are a lot of languages around the world. Therefore UN (United Nation) has developed an International 
language that can unite all the countries over the world. They are Arabic, Chinese, Russian, French, Spanish as well as English.

Karademir and Gorgoz (2019) stated that English is an official or semi-official language in more than 60 nations worldwide, and two-thirds of science articles are in English. Based on the following statement, the researcher assumes that English is currently one of the world's most common languages (Joseph-Jeyaraj \& Harland, 2019). English has been the common language throughout many multinational organizations, corporate and economic cooperation, partnership, scientific and education programs, and many other activities.

Nowadays, using technology in the learning process is necessary (Wong et al., 2017). As a teacher in the globalization era, the teacher should be a creative and innovative teacher. The teacher also needs to follow students' era by mastering in using technology as media in the learning process to build the students' interest while learning the material. Using technology, the teacher can avoid using the monothon the learning process and create students' interest from it and make an enjoyable environment around the classroom.

According to Almerich and Sigalés (Badia \& Iglesias, 2019), at least two types of competence in technology use must be developed by teachers. The first is technological competence, which refers to the handling and use of computers and basic and advanced computer applications; the second is pedagogical competence, which refers to the skills teachers use to make appropriate use of technological resources in the planning and implementation of the classroom instruction.

In this research, the researcher used audiovisual technology to develop students' listening comprehension through the movie, and the movie that the researcher used is Frozen 2 movie. Nystrom (2019) mentioned in his research that a movie could be a useful teaching tool to enhance students' various language skills. Using movies as learning media might help teachers deliver the material easily and make students interested in the learning process more. By watching a movie, students can understand the material easier than only listen to the audio. It is also entertaining the students and prevents them from getting bored easily.

As students watch Frozen 2 movies, they can learn the spoken language or familiar with the sound of vocabularies in daily conversation. Frozen 2 movies provide students an example of the dialog in daily conversation, the English used in an actual scenario. From viewing Frozen 2 movies, students can listen to the proper pronunciation, intonation, speech and tension. This movie introduces students to natural expression, so the student might become familiar with the words or conversation for daily activities. Frozen 2 movie is an animation movie that includes adventure and comedy genres inside the story. Students might love to watch, and Frozen 2 movies also provide them a great message about life, sacrifice, loyalty, bravery, and many others. This movie was released on 12 April 2019 in the United States, and the duration of this movie is around 2 hours, or to be specific is 131 minutes. Frozen 2 movie is a sequel of Frozen movie that has been released in 2013.

As described by Sobur as cited in Putri (2019), a movie or film is a form of expression that can educate and affect people's way of thought and feeling through the messages that the film sends. The concepts in the film always offer the meaning of life, encounters, etc. The film always influences and produces people by the messages. Atiyah and Izzah (2019) confirm that the advantages of using audiovisual (movie) are the ability to ensure authentic language (what they are communicating effectively). It also can help learners to conceptualize ideas and get in-depth thought on the topic, the motions that appeared in videos feature are always being motivational for the students, it can provide the available information or substitute for books when they are not available on a particular topic, and the dramatic reactions can bring historical events and personalities in life.

To achieve the research objectives, the researcher had some previous studies in the present study. First, Nystrom (2019) claimed in his research that a movie could work as a 
useful teaching tool to enhance students' various language skills. The movie provides a meaningful activity with authentic material that provides real language that makes students feel more motivated in the learning process. The research also conducted by Pratama (2018). He investigated the effectiveness of watching English movies to increase student's listening comprehension in SMA Negri 1 Manggar. The result of this research showed that watching an English movie can increase a student's listening comprehension significantly.

The result of the analysis data was consistent with the study conducted by Mostajeran et al. (2019) by the title of using Youtube videos on Iranian intermediate make and female EFL learners' listening skills development. This research included a participant who was assigned to two experimental groups and two gender-based control groups, each with 15 students. The summary of this study indicated the provision of instructional videos via Youtube have a substantial impact on the listening comprehension of Iranian intermediate male EFL learners. Second, the provision of instructional videos via Youtube substantially impacted Iranian intermediate female EFL learners' listening comprehension. Last, there is no substantial effect between providing youtube-based instructional videos on male and female EFL learners' listening comprehension.

The research of this study was carried out by Resi Silvia (2018). The researcher has figured out the effectiveness of using video to increase students' listening skills and attitudes at Adiwangsa University. The outcome of this study was established that the use of video to improve the listening comprehension of senior English students was successful, as shown by a post-test score that was substantially higher than the pre-test score.

To determine the success of this research, the researcher needs to know the students' problems while learning listening comprehension skills. Therefore, the researcher found several problems related to listening comprehension from the previous studies, they are pronunciation, native speakers' rate of speech, and the use of reducing form.

\section{Pronunciation}

As we teach English Foreign Learners (EFL), pronunciation of native speakers' has become a common issue for the students. Because of students' vocabulary limitation, students become unfamiliar with the sound although it has been produced before. It is making them difficult to understand in the form of the meaning of the words. It is an example of British English speaker's pronunciation as explained by Raihan and Deterding (2018) that British English speaker uses to lose of $/ \mathrm{r} /$ in words such as <four $>$ and $<$ farm $>$ and the occurrence of a back vowel /a; instead of /æ/ in words such as $<$ past $>$.

\section{Native speakers' rate of speech}

Fast speech rates are commonly viewed as one of the key variables influencing listening comprehension, especially for EFL students. When the students faced the speed race of the native speaker's speech, the faster the speed; the more students find it challenging to understand the message in the texts. For EFL students who still unfamiliar with English also lack their vocabulary, the speed of the native speaker's rate of speech is necessary because they need extra time to process the vocabulary and the messages of the speech at the same time. There are some related studies were found by Griffiths as cited in Chang (2018) who performed an experiment with 15 Japanese EFL learners listening to three different frequencies - relatively fast $(200 \mathrm{wpm})$, average $(150 \mathrm{wpm})$, and slow $(100 \mathrm{wpm})$. The three texts' effect reliably showed that students achieved poorer scores when the texts were transmitted at fast speech (200 wpm); however, there was no substantial gap in listening score between normal and slow speed. 
Native speakers often use "reduce forms" while speaking informally. Reduced forms are created when people speak very quickly, omit certain sounds from words, and merge several words. Reduced forms are considered bad English but they are very common in informal spoken English. Native speakers who use reduced forms will make EFL students more difficult to understand the text's message because they will find it as unfamiliar words or vocabularies in English. Ladefoged, as cited in Wong et al. (2017), gives an example of reduced form that native speakers usually use in informal spoken English. Gonna (going to), Gotta (got go), 'Cus (because), Dunno (I don't know), Couldya (could you), Kinda (kind of), Gimmie (give me), Lemme (let me), and many others. According to all of the explanations above, the researcher researches "enhancing listening comprehension through frozen 2 movie". This research aims to identify whether Frozen 2 movie as media in the learning process enhances students' listening comprehension or not.

\section{Theoretical Framework}

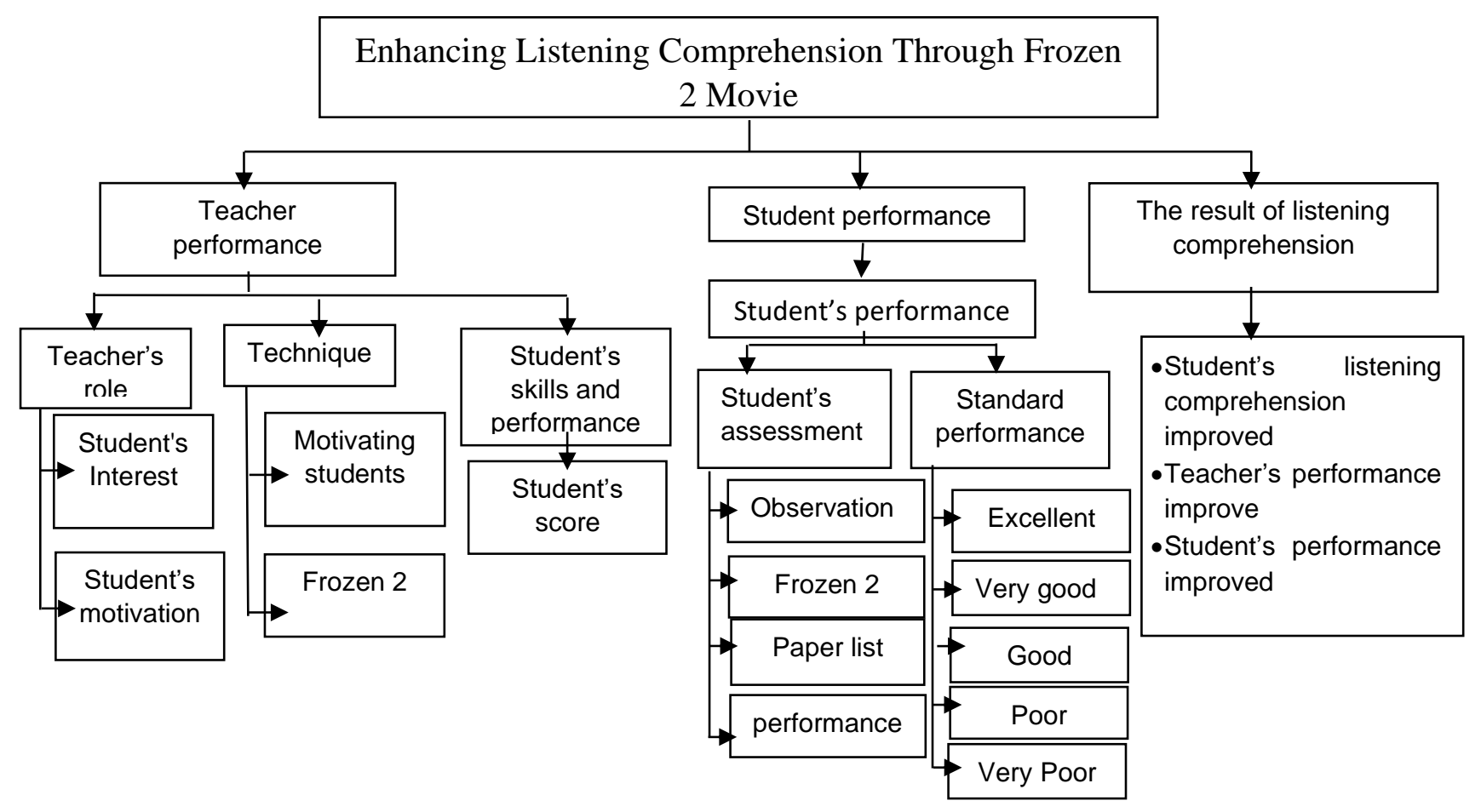

This research's theoretical structure is focused on the theoretical overview and the theories of the related research. As described earlier, listening is one of the skills that the students need to master in learning a language to understand what other people said and gain information from it. Listening is not a passive process. The listener could at least understand what the speaker tried to tell you. Kenneth quoted in Zheng (2018:226) expounded that listening comprehension consists of five compositions. One composition often relies on another, i.e. discrimination, interpretation of the messages, utilization or storing of the auditory memory, and decoding of a message. By listening, students can get information or knowledge easily.

However, listening to a foreign language is not a simple way of process; therefore, it is difficult to teach. Having a good strategy is a must for teachers in teaching listening comprehension for English Foreign learners (EFL). Students will have a difficult time also getting bored easily without supporting media or an interesting strategy. Therefore, the teacher needs to be creative to find or create new media or strategies for students to enjoy and be happy in receiving the material. Based on the explanation above, the use of media for the 
learning process is necessary for a teacher. One of the media that might help the student in increasing their listening comprehension is using the Frozen 2 movie. Using a movie, especially a popular and interesting movie such as Frozen 2 movie, can make students more enjoyable in the learning process. It is also can motivate students more.

Using the movie as media in increasing listening comprehension can be a good strategy for the teacher. The movie can develop their critical thinking, and the student becomes familiar with the sounds of native speakers. Students also can see and listen to the daily conversation of the native speaker and others.

\section{RESEARCH METHOD}

\section{Research Design}

This research used a quantitative research method to describe students' listening comprehension by watching the Frozen- 2 movie. In a quantitative research study, there are pre-experimental, true-experimental, and quasi-experimental designs. The design used in this study is a pre-experimental design using one group pre-test and post-test. In this research, the researcher collected the data by giving students pre-test questions before giving them the treatment. Afterward, the researchers give students special treatment. The treatment is teaching listening skills employing the Frozen-2 movie. In the last session, researchers distribute post-test questions to know whether there is a significant improvement in students' listening comprehension or not. In this study, researchers only compared the results based on the students' pre-test and post-test scores. The one-group pre-test post-test design involves a single group that is pre-test $(\mathrm{O} 1)$, treatment $(\mathrm{X})$, and post-test $(\mathrm{O} 2)$. The design in this research can be presented in Table 1 as follows.

Table 1

Table one group pre-test and post-test design

\begin{tabular}{lll}
\hline $\mathrm{O}_{1}$ & $\mathrm{X}$ & $\mathrm{O}_{2}$ \\
\hline
\end{tabular}

$\begin{array}{ll}\mathrm{O} 1 & \text { : pre-test } \\ \mathrm{X} & \text { : treatment } \\ \mathrm{O} 2 & \text { : post-test }\end{array}$

This study began from 4 November 2019 until 22 December 2020. The sample of this research consists of 16 students of Senior High School that live in Perum. Griya Serpong Asri, tangerang, Indonesia. This research was conducted by using Online Classroom, specifically via the Google Classroom platform.

\section{Instruments and Data Analysis}

In this research, researchers used pre-test and post-test to measure the significance of the improvement in the treatment of this research. Before the class began, the students are asked to join a WhatsApp group for this research to get the information quickly. The students are also asked to join GoogleClassroom that the researchers gave before the class begins because the lesson is held via google classroom. Before they go to this platform, students are prepared well for the teaching materials in listening activities. To get the data, researchers employ listening tests to find out students' listening comprehension using the Frozen-2 movie. The instrument covers some questions in the form of listening exercises. Researchers gave some questions as a pre-test to identify students' listening ability level before the researcher uses the main core, Frozen 2 movies, as the treatment for students' listening 
comprehension skills. The pre-test helped the researcher know how to handle students with the use of movie media in classroom activities.

Afterward, researchers used a movie as media in the learning process as the treatment of this research. The teacher showed Frozen 2 movie that was divided into 6 sections. Each section has 15-20 minutes and has some questions that students must answer directly. Thus, students answer the questions. Researchers and students discussed the questions before. Last, researchers gave some questions as a post-test to know whether the students improved their listening ability. After the researcher gathered all the data from students' pre-test and post-test score, the researchers calculate and compare the data by using IBM SPSS to know whether using the Frozen-2 movie has increase students' listening comprehension or not.

\section{RESEARCH FINDINGS AND DISCUSSION}

\section{Research Findings}

This study was aimed at investigating the effectiveness of the Frozen-2 movie in enhancing students' listening comprehension at senior high schools. This part contains the final result and discussion of this research. These contents aim to answer the research question about whether Frozen-2 movie does enhance students' listening comprehension. To know the effect of using Frozen-2 movie, researchers compare the result of students' listening comprehension pre-test and post-test scores. It can be seen in Table 2 that shows the result of students' listening comprehension pre-test and post-test scores.

Table 2

The result of students' listening comprehension

Paired Samples Statistics

\begin{tabular}{llllcc}
\hline & & Mean & $\mathrm{N}$ & Std. Deviation & Std. Error Mean \\
\hline Pair 1 & Pre-test & 84.69 & 16 & 8.056 & 2.014 \\
\hline & Post-test & 88.75 & 16 & 9.572 & 2.394 \\
\hline
\end{tabular}

From this output, the paired samples statistic table showed pre-test means' score was 84.69 while the post-test means' $88.75, \mathrm{~N}$ referred to the total of the sample that is 16 students. Standard deviation showed the heterogeneous that occurred in the data above and after using Frozen 2 movie were 8.056 and 9.572 and standard error of mean before and after using Frozen 2 movie were 2.014 and 2.394. From Table 2, it could be concluded that using Frozen 2 movie as media in the learning process has a significant improvement to students' listening comprehension skill. Meanwhile, the normality test can be seen in Table 3 as follows.

Table 3

Paired Sample Test

\begin{tabular}{|c|c|c|c|c|c|c|c|c|c|}
\hline \multicolumn{10}{|c|}{ Paired Differences } \\
\hline & & \multirow[t]{2}{*}{ Mean } & \multirow[t]{2}{*}{$\begin{array}{l}\text { Std. } \\
\text { Deviation }\end{array}$} & \multirow{2}{*}{$\begin{array}{l}\text { Std. } \\
\text { Error } \\
\text { Mean }\end{array}$} & \multicolumn{2}{|c|}{$\begin{array}{l}95 \% \text { Confidence Interval } \\
\text { of the Difference }\end{array}$} & \multirow[t]{2}{*}{$\mathrm{T}$} & \multirow[t]{2}{*}{ Df } & \multirow[t]{2}{*}{$\begin{array}{l}\text { Sig. } \\
\text { (2-tailed) }\end{array}$} \\
\hline & & & & & Lower & Upper & & & \\
\hline Pair 1 & $\begin{array}{l}\text { Pre-test and } \\
\text { post-test }\end{array}$ & -4.063 & 4.553 & 1.138 & -6.489 & -1.636 & -3.569 & 15 & .003 \\
\hline
\end{tabular}

Based on the calculation of the t-test, Table 3 showed a significant result. It can be seen from the result of the mean was 4.063. The standard deviation was 4.553. The standard error mean was 1.138. The lower interval was 6.489, and the upper interval was 1.636. Meanwhile, the result of the t-test was 3.569. The degree of freedom was 15 , and significant (2-tailed) was $0.003<\alpha(0.05)$. This study declares if the significance score is lower than $\alpha=$ 
0.05 , it can be concluded that the differences were significant. The results mean that the use of the Frozen-2 movie as media in the learning process positively affects students' listening comprehension.

Table 4

Test of Normality

\begin{tabular}{|c|c|c|c|}
\hline \multicolumn{4}{|c|}{ Shapiro-Wilk } \\
\hline & Statistic & $\mathrm{df}$ & Sig. \\
\hline Pre-test & .907 & 16 & .105 \\
\hline Post-test & .916 & 16 & .145 \\
\hline
\end{tabular}

Based on the output table of "test of normality" in the Shapiro-Wilk test section, is it known that the significant score for the pre-test is $0.105>\alpha(0.05)$, and the post-test significant score is $0.145>\alpha(0.05)$ where both of the significant scores were higher than $\alpha=$ 0.05. It means the pre-test and post-test data in this research are normal, and the data can be preceded to the next statistical test. It is presented in Table 5 and Figure 1 as follows.

Table 5

The Data Distribution of Pre-test Score

\begin{tabular}{|c|c|c|c|c|}
\hline No & Interval & Frequency & $\%$ & Category \\
\hline 1. & $95-100$ & 1 & 6.25 & Excellent \\
\hline 2. & $85-90$ & 10 & 62.5 & Good \\
\hline 3. & $75-80$ & 3 & 18.75 & Enough \\
\hline 4. & $55-70$ & 2 & 12.5 & Poor \\
\hline & Total & 16 & 100.0 & \\
\hline
\end{tabular}

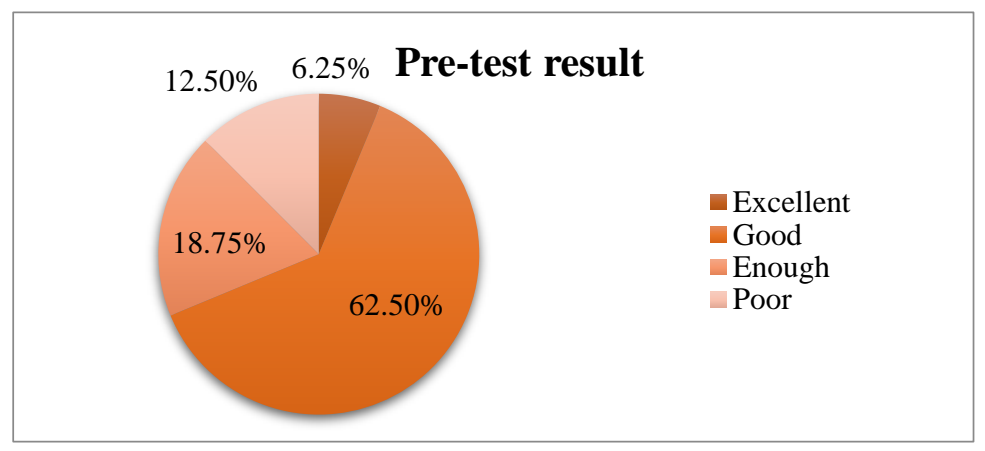

Figure 1. Classification of listening comprehension for pre-test

From the data above, the pre-test result of the pre-experimental classroom can be described there are two students who are poor (12.5\%), three students are enough $(18.75 \%)$, ten students are good (62.5\%), and one student is excellent (6.25\%). Meanwhile, the data distribution of the post-test can be presented in Table 6 and Figure 2 as follows.

Table 6

The Data Distribution of Post-test Score

\begin{tabular}{|c|c|c|c|c|}
\hline No & Interval & Frequency & $\%$ & Category \\
\hline 1. & $95-100$ & 6 & 37.5 & Excellent \\
\hline 2. & $85-90$ & 5 & 31.25 & Good \\
\hline 3. & $75-80$ & 4 & 25 & Enough \\
\hline 4. & $55-70$ & 1 & 6.25 & Poor \\
\hline
\end{tabular}




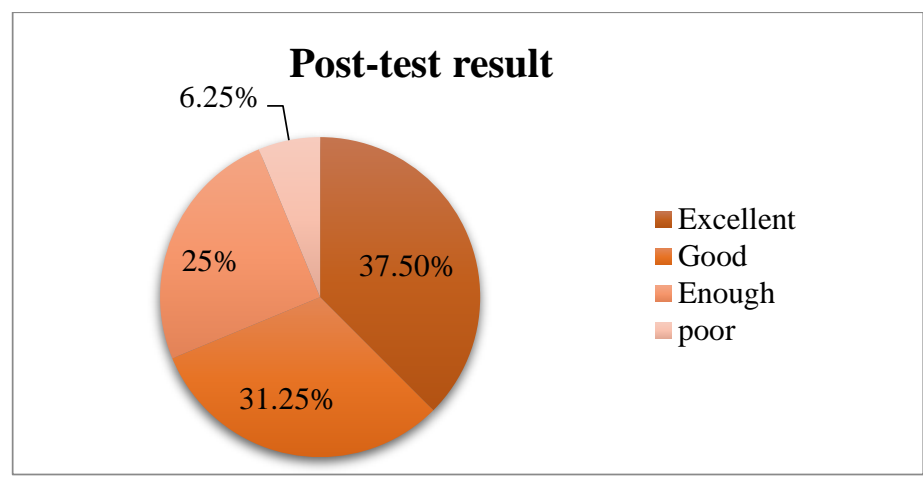

Figure 2. Classification of listening comprehension for pre-test

From Table 6 above, the post-test result of the pre-experimental classroom can be described that there is one poor student $(6.25 \%)$, four students are enough $(25 \%)$, five students are good $(31.25 \%)$, and 6 students are excellent $(37.5 \%)$. As students' pre-test and post-test result of scores was showed above, the diagram showed as follows.

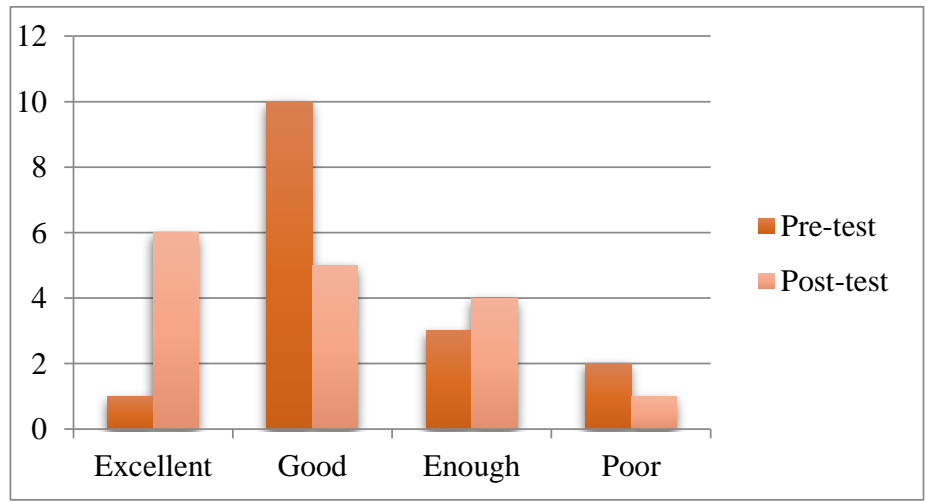

Figure 3. Pre-test and Post-test Score Result

\section{Discussion}

This study aims to investigate the effectiveness of the Frozen-2 movie in enhancing students' listening comprehension at senior high schools. The most important finding in my research result is whether there is a significant improvement of students' listening comprehension with or without using Frozen 2 movie as media in the listening comprehension learning process for senior high school around Griya Serpong Asri. The use of movies in enhancing language skills for EFL learners is considered as effective learning media (Kabooha, 2016; Pardede, 2011). To support this study, researchers tried to look for any previous studies in enhancing listening comprehension through movies. Some studies showed that movies are effective for improving students' speaking skills (Khan, 2015; Tuncay, 2014).

In this study, researchers employ a movie, the Frozen-2, to enhance students' listening comprehension. This movie use English. The language used is easy to understand. Before researchers distribute the listening materials, researchers design effective listening activities. Students are involved in taking notes of vocabulary from simple videos. It is oriented to uccostum students in making notes before watching the movie. Nassim (2018) informs that students should be facilitated with meaningful learning activities before moving to the main activities of listening. It is also in line with Wang (2015) who recommends various videos are needed in EFL context to facilitate students to carry out their learning tasks in the classes.

This study focuses on enhancing students' listening comprehension through giving pay attention to any texts and vocabulary from the Frozen-2 movie. Researchers collected the data 
by doing a pre-test, treatment, and post-test to know the significant improvement of using movies in learning listening comprehension spesifically using Frozen 2 movie. The pre-test and post-test scores were slightly different from the study reported above and proved to be 1355 for pre-test and 1420 for post-test. The average pre-test score was 84.69 and the average post-test score was 88.75 . It means that the pre-test and post-test variances were dissimilar.

In addition, based on the above numerical measurement, it can be shown that there is a clear gap between the average score and the outcome of teaching listening comprehension using Frozen 2 and without using it. Depending on the paired sample t-test table, tobtained was 3.569 and $t_{\text {critical }}$ at the level of significance $(p)=0.05$ was 2.602. Meanwhile, if $t_{\text {obtained }}$ is higher than $t_{\text {critical }}$ at the level of significance $(p)=0.05$, the null hypothesis is rejected and accepts the alternatives hypothesis $\left(\mathrm{H}_{1}\right)$. Then significant (2-tailed) is equal 0.003 with significant level $\mathrm{a}=0.05$ (2-tailed). Since the score is $0.003<\alpha(0.05), \mathrm{H}_{1}$ was accepted, and $\mathrm{H}_{0}$ was rejected.

From the result above, it can be established that teaching listening comprehension to senior high school students around Griya Serpong Asri by using Frozen 2 Movie has a significant impact. The study showed that the students' optimistic behavior could be that the current approach fits their desires and lifestyle. The majority of students are more likely to favor different techniques than normal, such as using only native speakers' audio (recording). Chan and Deborah as cited in Fussalam (2019) also claimed that from watching a movie it can improve several materials such as training the listening skill because students can familiarize their ear to hear words in English, training the speaking skill because when the students or listener focus on the actress or actor while speaking English they will be able to speak English accurately, and last training the writing skill, we can ask the students to resume from what they watched so they can increase their grammar, new vocabulary, use of an article, adverb placement and many others.

This also may imply that a movie can be a good media to help a teacher to teach English especially listening comprehension skills in the classroom. Also, it can help students to learn listening comprehension easier and more enjoyable than only using audio in listening classes. Using a movie as media in the learning process, students can learn more such as body language, facial expression, and gestures of the speakers provide additional information to the listener.

\section{CONCLUSION}

Defined as the study carried out around Perum. Griya Serpong Asri, the result from pre-test and post-test have a significant difference, it was proved by getting 1355 total score of pre-test and 1420 total score for post-test, then get 84,69 for average's score of pre-test and 88,75 for average's score of post-test. Therefore, it can be inferred that the use of Frozen 2 movie has a significant impact to teach students' listening comprehension for Senior High School around Perum. Griya Serpong Asri. It was proven by the t-test result in paired sample test that the value of the $t_{\text {obtained }}$ was 3.569 and $t_{\text {critical }}$ at the level of significance $(p)=0.05$ was 2.602 , meanwhile if $t_{\text {obtained }} \geq t_{\text {critical }}$ at the level of significance $(p)=0.05$, the null hypothesis $\mathrm{H}_{0}$ is rejected and accepts the alternatives hypothesis $\left(\mathrm{H}_{1}\right)$. Then the significant (2-tailed) is equivalent to 0.003 with a significant level $a=0.05$ (2-tailed). Since the score is $0.003<\alpha$ (0.05), $\mathrm{H}_{1}$ was approved and $\mathrm{H}_{0}$ was refused. 


\section{REFERENCES}

Atiyah, F., Izzah, L. (2019). A Comparative Study on the Effectiveness of Using Direct and Audiovisual Methods for Enhancing Students Listening Comprehension. English Language in Focus (ELIF), Volume 2 (1),9-16 . Indonesia : English Department, FIP UMJ. DOI: 10.24853/elif.2.1.9-16

Badia, A., \& Iglesias, S. (2019). The science Teacher Identity and the use of technology in the Clasroom. Journal of Science Education and Technology, 1-10. DOI: https://doi.org/10.1007/s10956-019-09784-w

Chang, A. C. S. (2018) Speech rate in Second Language Listening. In John I. Liontas (Ed.), The TESOL Encyclopedia of English Language Teaching ( $1^{\text {th }}$ Ed.), 3.

Eberhard., David, M., Gary, F. S., \& Charles, D. F (eds). (2020). Ethnologue: Languages of the World. Twenty-third edition. Dallas, Texas: SIL International. Retrieved 2 March, 2020. From https://www.ethnologue.com/guides/countries-most-languages

Joseph Jeyaraj, J., \& Harland, T. (2019). Linking critical pedagogy practice to higher education in Malaysia: insights from English language teachers. Asia Pacific Journal of Education, 39(1), 1-13. https://doi.org/10.1080/02188791.2019.1572590

Kabooha, R. H. (2016). Using Movies in EFL Classrooms: A Study Conducted at the English Language Institute (ELI), King Abdul-Aziz University. English Language Teaching, 9(3), 248-267.

Karademir, C. A., \& Gorgoz, S. (2019). English Teachers' Problems Encountered in Teaching Four Basic Language Skills. International Education Studies, 12(4), 118-127. DOI: 10.5539/ies.v12n4p118

Khan, A. (2015). Using films in the ESL classroom to improve communication skills of nonnative learners. ELT Voices, 5(4), 46-52.

Makiabadi, H., \& Square, A. (2019). Learning English Listening and Speaking Through Bbc Voa Podcasts: Teaching English with Technology, 19(2), 101-108. http://www.tewtjournal.orghttp//www.tewtjournal.org

Mostajeran, R., Mahali, M. I., \& Putra, R. A. S. (2019). Impact of Using YouTube Videos on Iranian Intermediate Male and Female EFL Learners' Listening Skill Development. International Journal of Foreign Language Teaching \& Research, 7(28), 75-83. Retrieved from http://jfl.iaun.ac.ir/mobile/article_664513.html

Nassim, S. (2018). Digital storytelling: An active learning tool for improving students' language skills. PUPIL: International Journal of Teaching, Education and Learning, 2(1), 14-29.

Nystrom, K. (2019). Film as a Tool in English Teaching: A Literature Review on the Use of Film to Develop Students Linguistic Skills and Critical Thinking in Upper Secondary EFL Classrooms. Thesis of English program Dalarna University. 1-19. Retrieved from https://www.diva-portal.org/smash/ record.jsf?pid=diva2\% 3A1355280\&dswid=5112

Pardede, P. (2011). Using short stories to teach language skills. JET (Journal of English Teaching), 1(1), 14-27.

Pratama, Z. (2018). Improving Student's Listening Skill Through Watching English Movie. Thesis of English Education Department Syarif Hidayatullah State Islamic University Jakarta. 52.

Putri, N. A. D. (2019). Analysis of Teaching Strategy Found in Poetry Class on The Movie Dead Poets Society Directed by Peter Weir. Thesis of English Language Education Department University of Muhammadiyah Malang. 7.

Queiros, A., Faria, D., Almeida, F. (2017). Strength and Limitation of Qualitative and Quantitative Research Method. European Journal of Education Studies, 3(9), 369386. Portugal: INESC TEC. DOI: http://dx.doi.org/10.5281/zenodo.887089 
Raihan, N., Deterding, D. (2018). The Fallacy of Standard English. In O. kang, R. I. Thomson, \& J. M. Murphy (Eds.), The Routledge Hanbook of Contemporary English Pronunciation. 204. Abingdon and New York: Routledge.

Robert, C., Havlicek, J., \& Schaal, B. (2020). Human Olfactory Communication: Current Challenges and Future Prospects. Philosopical Transactions The Royal Society Publishing, 1-11. DOI: https://doi.org/10.1098/rstb.2019.0258

Silvia, R. (2018). Using Videos to Increase Midwifery Students Listening Skills and Student's Attitude. Curricula: Journal of Teaching and Learning, 3(2), 87-94. DOI: 10.22216/jcc.2018.v3i2.2885

Tragant, E., \& Vallbona, A. (2018). Reading while listening to learn: Young EFL learners' perceptions. ELT Journal, 72(4), 395-404. https://doi.org/10.1093/elt/ccy009

Tuncay, H. (2014). An Integrated Skills Approach Using Feature Movies in EFL at Tertiary Level. Turkish Online Journal of Educational Technology-TOJET, 13(1), 56-63.

Wang, W. (2016). Learning to Listen: The Impact of a Metacognitive Approach to Listening Instruction. Asia-Pacific Education Researcher, 25(1), 79-88. https://doi.org/10.1007/s40299-015-0235-4

Wang, Z. (2015). An analysis on the use of video materials in college English teaching in China. International Journal of English Language Teaching, 2(1), 23-28.

Wong, S. W. L., Tsui, J. K. Y., Chow, B. W. Y., Leung, V. W. H., Mok, P., Chung, K. K. H. (2017) Perception of Native English Reduced Forms in Adverse Environments by Chinese Undergraduate students. Journal of Psycholinguistic Research, 46(1), 11491165. DOI : 10.1007/s10936-017-9486-y

Zheng, J. (2018). The Metacognitive Strategy in English Listening Comprehension. Theory and Practice in Language Studies, 8(2), 226-231. DOI: http://dx.doi.org/10.17507/tpls.0802.07 